\title{
Access to a genuinely independent and impartial trial: a review of the sixteenth sustainability goal completeness
}

\author{
Rostyslav Sopilnyk* \\ Juliusz Piwowarski*
}

Received: 2021-03-03

Accepted: 2021-05-12

DOI: http://doi.org/10.46489/lbsh.2021-1-1-5

Abstract. The sixteenth sustainability goal is about equality in access to justice. However, according to some events in Eastern Europe, access is insufficient. The court must be genuinely independent and impartial. In this regard, we decided to find arguments in favour of expanding the sixteenth sustainability goal. A review of the sources and a theoretical study indicated a clear link between judicial independence and sustainable development. We used the method of doctrinal research. ECtHR cases have become our data for qualitative analysis. We have reaffirmed that judicial independence is the condition of the rule of law. It means conduction of proceedings without any pressure or interference on a judge, particularly from other branches of government. We argue that the entire independence of the judiciary appears on the background of the subjective and objective independence of the judge. In addition, this study demonstrates that judicial independence is a condition for sustainable development. It is associated with public trust and public confidence in the reality of such independence. In the example of equality of parties, we pointed out that there is no need to detail the sixteenth goal further. With our study, we wish to breathe new energy into the sixteenth goal of sustainable development.

Keywords: access to justice, the right to a fair trial, sustainable development, sustainable development goals, ECtHR practice.

\footnotetext{
* Rostyslav Sopilnyk, DSc, Professor, Main Division of the National Police in Lviv oblast, General Hryhorenko Square, 3 79000 Lviv, Ukraine, E-mail: rsopilnyk01@gmail.com, ORCID: https://orcid.org/0000-0001-9942-6682 (corresponding author)

** Juliusz Piwowarski, DSc, Professor, rector, Higher School of Public and Individual Safety «Apeiron» in Cracow, Krupnicza 3, 31-123 Kraków, Poland, ORCID: https://orcid.org/0000-0002-9196-1194
} 


\section{INTRODUCTION}

As we know, the sixteenth goal of sustainable development (United Nations, 2015) is equal access to justice. Practice shows that there can be different types of justice, access to which is provided by states. In a weak democracy or dictatorship, access to justice is not a sound basis for sustainable development. In this case, we have to apply specific criteria, as the European Convention recommends (European Court of Human Rights, \& Council of Europe, n.d.). Article 6 of the Convention details the right to a fair trial as the right of everyone to access an independent and impartial trial. This article contains other requirements for the court, which are crucial for sustainability. Alsheban, Dr. A. (2017) noted that international human rights instruments refer to a fair trial by "an independent and impartial tribunal".

Independent and impartial trial is a prerequisite for a democratic society (Parliamentary Assembly, 2010). Judicial independence is essential for ensuring the rule of law and a fundamental guarantee of a fair trial (Consultative Council of European Judges, 2001). Judicial independence and its separation from the executive are the cornerstones of the rule of law, from which there can be no exceptions (Hoffmann-Riem, W., 2014). Hossain Mollah, A. (2012) emphasized that an independent judiciary is "the sin qua non of democracy and good governance".

De jure judicial independence is not systematically related to sustainability, whereas de facto judicial independence is highly significantly and robustly correlated with growth (Voigt, S., Gutmann, J., \& Feld, L. P., 2015).

The method of selecting and retaining justices of courts has a significant and direct effect on entrepreneurial activity (Dove, J. A., 2015).

Judicial reform can stimulate judicial efficiency and entrepreneurship (Chemin, M., 2009).

The country's levels of democracy and peacefulness had a significant and positive relationship with citizens' confidence in the courts (Boateng, F. D., 2020).

\section{1. Literature Review}

The issue of ensuring judicial independence is relevant for all countries. Keith, K. J. (2017), on the example of The International Court of Justice, proved the importance of independence procedures.

Boryslavska, O. (2021) noted the particular relevance of judicial independence in the context of judicial reforms in several Eastern European countries (Serbia, Northern Macedonia, Poland, Hungary, Romania, Moldova, and Ukraine).

Kovács, K., \& Scheppele, K. L. (2018) investigated modern threats to judicial independence in Hungary and Poland, showing how first the constitutional courts and then the ordinary judiciary were brought under the control of political forces.

Rudenko, M., Malinovska, I., \& Kravtsov, S. (2021) described the problems of an independent court in the light of the purification and lustration initiatives in Ukraine.

Hossain Mollah, A. (2012) investigated the status of independence of the judiciary in Bangladesh. From the beginning of British colonial rule, the scholar proved that separation of the judiciary from the executive had been a continuing debate.

Armendáriz, P. (2020) explored the primary determinants of internal judicial independence in three Latin American countries (Chile, Peru, and Ecuador). $\mathrm{He}$ proved that judges' autonomy from politicians does not necessarily follow the same path as lower-court judges' independence from their hierarchical superiors.

The independence of the judiciary is a condition of the rule of law. Spano, R. (2021) noted that the rule of law is a constitutional principle under the European Convention on Human Rights. The author reflects on the "symbiotic" relationship in judicial independence between the Strasbourg Court and the Court of Justice of the European Union.

The independence of the judiciary is directly related to the trust in the judiciary. However, Armendáriz, P. (2020), in the example of Ecuador, proved that citizens' trust and support for the judiciary could increase despite decreasing levels of judicial 
independence, which arise from the approval of the executive performance.

Yeung, L. L. (2019) investigated the impact on judges' deviation from independence and impartiality. The author emphasized that citizens have lower levels of trust in the judicial system if courts and judges are biased and unpredictable.

The existence of an independent court is vital for the development of state power in general. As Kim, J. (2007) proved in the example of Korea, the increased level of enforcement has become a cornerstone for the consolidation of the rule of law and good governance.

Voigt, S., \& Gutmann, J. (2015) emphasized that the actual independence of the judiciary correlates with lower levels of corruption.

There are problems with assessing the independence of the judiciary. Therefore, the standards of the organization of the judiciary remain relevant. Piana, D. (2017) examined judicial reform in Italy based on European standards and noted their importance for judicial independence. Kosař, D., \& Spáč, S. (2018) researched judicial independence and accountability measuring methods. The authors stressed the importance of developing assessment methods in the context of new challenges.

Vuille, J., Lupària, L., Taroni, F. (2017) tried to identify opportunities to assess the independence of the judiciary based on an analysis of the European Convention on Human Rights. The authors recommended that states pay attention to the effectiveness of the legalization of the right to a fair trial.

Sakara, N. (2021) investigated specific criteria of a fair trial based on the case-law of the ECtHR. The author argued that the relevant criteria should be the basis for reforming national legislation.

\section{2. Theoretical basics of judicial independence}

Judicial independence is, in procedural terms, the complete independence and impartiality of judges. Judges must be impartial, free from any connection, attachment or prejudice that affects or may be perceived as affecting the judge's ability to make independent decisions about parties.

Judicial independence should be guaranteed by the state and enshrined in the country's Constitution or laws (Seventh United Nations Congress on the Prevention of Crime and the Treatment of Offenders, 1985). Justice requires that everyone has the right to a fair and public hearing in a competent, independent and objective court following the principles enshrined in the Universal Declaration of Human Rights, the International Covenant on Civil and Political Rights and other instruments. States must have an independent judiciary (Seventh United Nations Congress on the Prevention of Crime and the Treatment of Offenders, 1985). Following a study of the situation in Ukraine, the Parliamentary Assembly of the Council of Europe stated that the reform of the judiciary and the justice system should be aimed, inter alia, at eliminating all forms of corruption in the judiciary while ensuring the independence of the judiciary (Parliamentary Assembly, 2010). However, as stated in the Opinion of the European Commission for Democracy through Law (2004), the principle of independence is not in itself a guarantee of a democratic model if it is not subject to the rule of law.

The independence of the judiciary is not an end in itself but a necessary condition for the realisation of the human right to a fair trial. Without judicial independence, the right to a fair trial cannot be realised, and the judiciary's credibility is undermined (The Committee of Ministers of the Council of Europe, 2010). The judiciary must hold the trust not only of the parties but also of society as a whole. The judge must be genuinely free from any prejudice or influence and be so in the eyes of society.

According to the Bordeaux Declaration, society has an interest in ensuring the rule of law through fair, impartial and effective justice. A fair administration of justice requires equality in the prosecution and defence and respect for the independence of the judiciary, adherence to the principle of separation of powers, and the binding force of final judgments (Consultative Council of European Judges, Consultative Council of European Prosecutors, 2009). The Bangalore Principles state that the independence of the judiciary is a prerequisite 
for the rule of law and a fundamental guarantee of a fair trial (Judicial Group on Strengthening Judicial Integrity, 2002).

The independence of the judiciary generates the independence of courts and judges. Real judicial independence has three preconditions:

- the presence of political will (Bachmann, K., \& Fatić, A., 2019);

- practical adherence by judges to the standards of judicial ethics (Simental Franco, V. A., 2017);

- clear link between judges' independence and their responsibilities (Mocan, N., Bielen, S., \& Marneffe, W., 2020).

We can distinguish between external and internal independence. External independence means the independence of the judiciary from the influence of the legislative or executive branches. Internal independence means that the judges feel no illegal influence in decisionmaking.

In this study, we aim to justify the possibility of specification the sixteenth goal of sustainable development. We believe that not just access but access to an independent and impartial trial is essential for sustainable development. At the same time, independence for sustainable development must be real, not declarative. Focusing on European and international standards of the judiciary and the case-law of the European Court of Human Rights, we have considered the following research questions.

$\mathrm{RQ}_{1}$. What is the meaning of the real independence of the judiciary?

$\mathrm{RQ}_{2}$. Are there general criteria for real independence of the judiciary?

$R_{3}$. Can we attribute other elements to the independence of the judiciary?

\section{METHODS}

Sustainable development goals have a global impact. The government of each state tries to adapt them to domestic legislation. Such adaptations, and especially the ways to achieve the goals, can vary significantly from country to country. Reducing deviations is achievable if the goals are as specific as possible.

This study is structured as follows. First, we defined the content of the real judicial independence. Then we summarised the criteria, the fulfilment of which testifies to the achievement of real judicial independence. Finally, we explored the possibility of developing an independent trial concept on the principle of equality of parties.

The general method we used in this study is doctrinal research (Pradeep M., D., 2019). We obtained data for qualitative analysis from open sources. Everyone can repeat our research and convince the accuracy of the conclusions.

We have considered the limitations of the ECtHR case-law study (Weiden, D. L., 2009; Hrestic, M.-L. (2013)).

\section{RESULTS}

\section{1. The real judicial independence}

Analysing the case of Bochan v. Ukraine (No. 2) (Application no. 22251/08), we have seen that the key issue is trust that courts in a democratic society should get in society. Only independent and impartial courts can evoke such trust. As stated in le Compte, van Leuven and de Meyere $v$. Belgium (Application no. 6878/75; 7238/75), the court must be independent of both the authorities and the parties to the proceedings.

A sign of independence is whether the court functions independently (Moiseyev v. Russia (Application no. 62936/00). In Feldman v. Ukraine (no. 2) (Application no. 42921/09) ECtHR, deciding whether the court can consider independence within the meaning of Article $6 \mathrm{~S}$ 1 of the Convention, drew attention, inter alia, to the existence of guarantees against external pressure and the question whether court showed signs of independence.

We can find the meaning of signs of independence in the case file of Belilos $v$. Switzerland (Application no. 10328/83). In this case, ECtHR noted that the court is a jurisdictional body that decides issues within its competence based on the rule of law, following the established procedure. So, the court must meet several other requirements: independence from executive power, impartiality, and stability. The trial must provide the accused with guarantees, some of which Article $6 \$ 1$ of the Convention contains.

In the case Altay $v$. Turkey (No. 2) (Application no. 11236/09), the applicant alleged a double violation of Article $6 \$ 1$ of the 
Convention. On the one hand, they complained that an independent and impartial tribunal had not heard his case. The state security courts were a different structure from the criminal courts of general jurisdiction. On the other hand, he complained about the lack of a fair trial by the State Security Court in respect of his conviction based on coercive evidence.

In the case of Agoudimos and Cefallonian Sky Shipping Co. v. Greece (Application no. 38703/97), the applicants complained that the legal interference in the proceedings against them, in which the NAT Fund had been a party, had violated their right to a fair trial under Article 6 $\int 1$ of the Convention. The court confirmed that, in principle, the legislator has no prohibition in adopting new provisions that have retroactive effect. Such provisions may govern rights arising under applicable law. Nevertheless, the principles of the rule of law and the notion of a fair trial embodied in Article 6 preclude any interference by the legislature in administering justice to influence the settlement of a dispute. The only exception can be the cases of reasons arising out of the general interest. So, the ECtHR found a violation of the Convention.

\section{Criteria of real judicial independence}

Judges must be impartial in making judgments, free from any connection, attachment or prejudice that affects or may be perceived as affecting the judge's ability to make independent decisions. In de Cubber $v$. Belgium (Application no. 9186/80), ECtHR states that it is the responsibility of each state to establish courts under the principles of impartiality.

In order to determine whether a court is independent, it is necessary to pay attention to the appointment method and the term of their powers, as well as to the existence of guarantees against external pressure and the presence of signs of independence (Bochan v. Ukraine (No. 2) (Application no. 22251/08). For example, the sixyear term of office of the members of the Board of Appeal in the case of le Compte, van Leuven and de Meyere v. Belgium (Application no. $6878 / 75$; 7238/75), ECtHR noted as a guarantee of judicial independence.

The ECtHR acknowledges the existence of two components of impartiality: subjective and objective (Pullar v. The United Kingdom (Application no. 22399/93). In Campbell and Fell v. The United Kingdom (Application no. 7819/77; 7878/77), ECtHR has stated that assessing the independence of a court cannot be limited to subjective criteria but also considers objective ones.

Criteria of impartiality within the meaning of paragraph 1 of Art. 6 of the Convention are defined as follows. According to the subjective criterion, the personal beliefs and conduct of the individual judge are taken into account, i.e. whether the judge was biased or impartial in the case. The objective criterion is the absence of any doubts about its impartiality (Belukha $v$. Ukraine (Application no. 33949/02)). In terms of subjective criteria, the court's impartiality is recognised until evidence to the contrary is provided (Pullar v. The United Kingdom (Application no. 22399/93)).

In Bochan v. Ukraine (No. 2) (Application no. 22251/08), the applicant complained under Article $6 \$ 1$ of the Convention about the outcome and unfairness of the civil proceedings, arguing that the courts were not independent and impartial. In particular, they complained that the city and regional courts had rendered their decisions under pressure from the Supreme Court of Ukraine, which was interested in a particular outcome. In this case, the ECtHR emphasised that impartiality should be determined according to a subjective criterion based on the behaviour of an individual judge. At the same time, noted ECtHR, it is necessary to take into account the objective criterion, namely - whether there were sufficient guarantees to eliminate any doubts about judicial independence.

In Daktaras v. Lithuania (Application no. 42095/98), the ECtHR stated that Article 6 \& 1 of the Convention contained two aspects of the impartiality requirement. First, the court, while hearing the case, must be subjectively impartial, i.e. no member must show any personal interest or bias. A judge is considered to be impartial if there is no evidence to the contrary. Secondly, such a court must be objectively impartial, i.e. it must provide sufficient guarantees to exclude any legitimate doubts in this regard. According to the second criterion, it is necessary to determine whether there are facts, the 
establishment of which may cast doubt on the impartiality of judges.

Impartiality should be determined by subjective assessment based on a particular judge's personal beliefs and conduct in a particular case. No member of the court should show any personal commitment or prejudice $(F$ Salov v. Ukraine (Application no. 65518/01).

In the case of Findlay v. The United Kingdom (Application no. 22107/93), ECtHR emphasised that subjectively the court should not be exposed to emotions, objectively - should not allow any doubts.

In Romanov v. Ukraine (Application no. 63782/11), the ECtHR stated that the absence of impartiality means the absence of a court established by law. A judge who participated in the case's decision in the court of the first instance may not participate in its retrial after the case's return by the court of higher instance. In this case, it is a question of eliminating doubts about the impartiality of the court. Failure to comply with this rule means that the appeal is considered by a court whose impartiality is under question.

In Remli v France (Application no. 16839/90), one of the judges expressed a racist argument. The plaintiff, therefore, lodged a complaint alleging that the court hearing his case was not impartial. The Commission concluded that a dismissal procedure was possible in this case.

In Buscemi v. Italy (Application no. 29569/95), the applicant complained about the bias of the President of the Juvenile Court. He stated that his case had not been heard by a court whose chairman he could have debated. In this regard, the ECtHR emphasised that judges must exercise sufficient restraint in the performance of their duties to guarantee a reputation for impartiality.

In Sovtransavto Holding v. Ukraine (Application no. 48553/99), ECtHR stated that impartiality is not always realised. So, the applicant complained that his case had not been considered impartially. The government insisted that Ukrainian law provided many guarantees for the impartiality and independence of the courts and their members. The applicant did not deny the existence of Ukrainian law of rules guaranteeing the independence and impartiality of the courts. However, he insisted that compliance with these rules is not always ensured in practice.

Based on the European Court of Human Rights case law, we argue that the impartiality of the court is determined based on subjective and objective criteria. Subjective criterion means the absence of personal interest or bias in the personal beliefs and conduct of a particular judge in a particular case; objective affects the functional activities of the court, means no doubt about its impartiality.

\section{DISCUSSION: DEVELOPING AN INDEPENDENT TRIAL CONCEPT (ON THE EXAMPLE OF PARTIES' EQUALITY)}

Our research proves that equal access to justice does not always mean fulfilling the sixteenth goal of sustainable development in the spirit of sustainability. We convince that the sixteenth goal should be expanded (at least in national sustainable development strategies) by including the characteristics of the court to which access should be provided. Such a court must be independent and impartial. But why not improve this goal further? Consider, for example, the principle of equality of parties, which has a logical link to both the idea of a fair trial and equal access to justice.

A fundamental aspect of the right to a fair trial is that the consideration of a criminal case, including procedural elements, must be adversarial. In this process, the principle of equality of parties, i.e. prosecution and defence, must be ensured. Equality is one of the foundations of the modern concept of a fair trial. It is first and foremost crucial for everyone to have access to justice and the opportunity to exercise the right to judicial protection freely, quickly, and without hindrance, regardless of belonging to a particular social group or other personal characteristics. The content of this principle we can disclose in the following elements:

a) equality of all participants in the trial before the law and the court, regardless of race, colour, political, religious and other beliefs, sex, ethnic and social origin, property status, place of residence, language and other characteristics;

b) equality of procedural rights concerning proving legal position before a court, as well as obligations arising from procedural law; 
c) equality of the application of the substantive and procedural law by the court, regardless of the legal and social status of the person, the factual and legal circumstances of the case;

d) access to a single judicial system for all, which provides the possibility of considering the merits and appealing.

In the Lucà v. Italy (Application no. 33354/96), the applicant complained of violating his right to a fair trial. He had no opportunity to question the prosecution witnesses. He asserted that he had been convicted based on testimony given to the prosecutor by another accused in connection with the case. However, the applicant was not allowed to interrogate the second accused or to obtain his explanations. The ECtHR pointed out that the national law primarily conduct the admissibility of evidence, and, as a general rule, national courts give the general assessment of this evidence. Guided by its case law, the ECtHR emphasised that, according to the Convention system, cross-examination of prosecution witnesses, in the broadest sense, does not necessarily have to take place during a trial. Although evidence, including prosecution evidence, usually has to be examined during a trial, specific circumstances, such as those mentioned in this case, make it difficult or impossible to repeat previously given evidence in open court. In such cases, Article 6 requires only that the accused be given an appropriate opportunity to rebut that evidence, at least during the trial. The ECtHR completely rejected the government's argument that it was necessary to defend the second accused's right to remain silent, as he had been summoned to repeat at a public hearing the statements he had made earlier. However, the main issue, in this case, was not the right to remain silent. The second accused retained the right to remain silent and not to testify against him. However, if he used this right, his previous testimony could be used against other persons as serious evidence of guilt only if the first accused had previously had the opportunity to crossexamine him at a certain stage of the proceedings. The ECtHR, therefore, found a violation of Article $6 \int S 1$ and 3 (d) of the European Convention on Human Rights.
The principle of equality of parties in the process (in the sense of a "fair balance" between the parties) requires that the court give each party a reasonable opportunity to present the case in conditions that do not put that party at a significant disadvantage vis-à-vis the other party. Thus, in Kurnetsov and others v. Russia (Application no. 184/02), the applicants alleged a violation of Art. 6 of the Convention because they were denied a fair trial, namely:

a) the judge of the first instance treated them with prejudice and openly demonstrated a preference for the other party;

b) in their case, the principle of equality of the parties was not ensured;

c) the court refused to consider their evidence and came to completely erroneous and unfounded conclusions.

We draw on these examples and insist that reflecting the requirement of independence and impartiality is sufficient to significantly improve the wording of the sixteenth goal of sustainable development. An independent and impartial tribunal is governed solely by the law. Given the excellent quality of the law, it will mean no risk of inequality, lack of protection or excessive length of proceedings.

The resulting research suggests that the independence and impartiality of the judiciary is a condition for compliance with the sixteenth goal of sustainable development. The independence of the judiciary testifies to the rule of law and the permanence of democracy.

The results of this study can be helpful for future sustainable development planning. States can use these recommendations as a basis of a national sustainable development strategy for meeting the sixteenth global goal.

\section{Limitation}

We have abstracted from the current worldwide situation in ensuring the independence of the judiciary. This study can serve as a basis for future study of facts and data concerning the independence of the judiciary and its impact on sustainable development.

In this study, we relied on a European approach to an independent court. Dissemination of the study's findings to other 
regions requires clarification of local features of law and culture.

This study is basing on the ECtHR case law. New ECtHR decisions may necessitate clarification of the study's findings.

\section{CONCLUSION}

In this study, we briefly discussed the prospects for an expanded interpretation of the sixteenth global goal of sustainable development. We argued that sustainable development should be based on access to an independent and impartial trial. We have established that the independence of the judiciary is a condition of the rule of law. It consists of the administration of justice without any pressure or interference from other branches of government. The real independence of the judiciary appears in the background of the subjective and objective independence of the judge. Judicial independence as a condition for sustainable development is associated with public trust and public confidence in the reality of such independence. In discussion, we pointed out that the concept of judicial independence can cover a lot of fair trial elements for sustainable development. The study results have the potential for implementation at different levels of government, in rule-making and law enforcement, which will breathe new energy into the sixteenth goal of sustainable development.

\section{References}

1. Agoudimos and Cefallonian Sky Shipping Co. v. Greece (Application no. 38703/97) (2011). ECtHR. https://www.bailii.org/eu/cases/ECHR 2001/406.html

2. Alsheban, Dr. A. (2017). Judicial Impartiality and Independence of the Judiciary (Comparative Study). IOSR Journal of Humanities and Social Science, 22(05), 3744. https://doi.org/10.9790/0837-2205023744

3. Altay v. Turkey (No. 2) (Application no. 11236/09)

(2019).

ECtHR. https://hudoc.echr.coe.int/spa\# $\{\% 22$ ite mid\%22:[\%22001-192210\%22]\}

4. Armendáriz, P. (2020). Trusting the Dependent Judiciary: Evidence From Ecuador. Revista de Ciencia Política (Santiago), ahead. $\quad$ https://doi.org/10.4067/S0718$\underline{090 \times 2020005000120}$
5. Bachmann, K., \& Fatić, A. (2019). Accepting the political face of international criminal justice. International Journal of Law, Crime and Justice, 57, 2635. https://doi.org/10.1016/i.ijlci.2019.01.005

6. Basabe-Serrano, S. (2014). Some determinants of internal judicial independence: $\mathrm{A}$ comparative study of the courts in Chile, Peru and Ecuador. International Journal of Law, Crime and Justice, $\quad 42(2), \quad 130$ 145. https://doi.org/10.1016/j.ijlci.2014.01.010

7. Belilos v. Switzerland (Application no. 10328/83)

(1988).

ECtHR. https://www.uio.no/studier/emner/jus/ humanrights/HUMR5120/h06/undervisningsmat eriale/Belilos v Switzerland.doc

8. Belukha v. Ukraine (Application no. 33949/02)

(2006).

ECtHR. https://hudoc.echr.coe.int/eng\#\{\%22ap pno $\% 22:[\% 2233949 / 02 \% 22], \% 22$ itemid $\% 22:[\% 2$ 2001-77950\%22]\}

9. Boateng, F. D. (2020). Legitimizing the Judiciary: A Multilevel Explanation of Factors Influencing Public Confidence in Asian Court Systems. Asian Journal of Criminology, 15(4), 285299. https://doi.org/10.1007/s11417-020-093161

10. Bochan v. Ukraine (No. 2) (Application no. 22251/08) (2015). ECtHR. https://hudoc.echr.coe.int/fre\#\{\%22ite mid\%22:[\%22001-152331\%22]\}

11. Boryslauska, O. (2021). Judicial Reforms in Eastern Europe: Ensuring the Right to a Fair Trial or an Attack on the Independence of the Judiciary? . Access to Justice in Eastern Europe, 4(1), 122-142. https://doi.org/10.33327/AJEE-18-4.1$\underline{\mathrm{a} 000049}$

12. Buscemi v. Italy (Application no. 29569/95) (1999). ECtHR. http://www.worldlii.org/eu/cases/ECH $\underline{\mathrm{R} / 1999 / 70 . \mathrm{html}}$

13. Campbell and Fell v. The United Kingdom (Application no. 7819/77; 7878/77) (1984).

ECtHR. https://hudoc.echr.coe.int/fre\# \{\%22ite mid\%22:[\%22001-57456\%22]\}

14. Chemin, M. (2009). The impact of the judiciary on entrepreneurship: Evaluation of Pakistan's “Access to Justice Programme". Journal of Public Economics, 93(1-2), 114125. https://doi.org/10.1016/i.jpubeco.2008.05.0 $\underline{05}$

15. Chemin, M. (2021). Can judiciaries constrain executive power? Evidence from judicial 
reforms. Journal of Public Economics, 199, 104428. https://doi.org/10.1016/i.jpubeco.2021.1 $\underline{04428}$

16. Consultative Council of European Judges, \& Consultative Council of European Prosecutors. (2009). Bordeaux Declaration 'Judges And Prosecutors in a Democratic Society". https://rm.coe.int/1680747391

17. Consultative Council of European Judges. (2001). Opinion No 1 (2001). https://rm.coe.int/1680747830

18. Daktaras v. Lithuania (Application no. 42095/98)

(2001).

ECtHR. http://hudoc.echr.coe.int/webservices/c ontent/pdf/001-58855

19. de Cubber v. Belgium (Application no. 9186/80)

(1984).

ECtHR. https://hudoc.echr.coe.int/ukr\#\{\%22ite mid\%22:[\%22001-57465\%22]\}

20. Dove, J. A. (2015). The effect of judicial independence on entrepreneurship in the US states. Economic Systems, 39(1), 7296. https://doi.org/10.1016/i.ecosys.2014.06.006

21. European Commission for Democracy through Law. (2004). Draft opinion on the draft law amending the Law of Ukraine On the office of the public prosecutor. https://www.venice.coe.int/webforms/ documents/?pdf $=$ CDL(2004)083-e

22. European Court of Human Rights, \& Council of Europe. (n.d.). European Convention on Human Rights as amended by Protocols Nos. 11 and 14 supplemented by Protocols Nos. 1, 4, 6, $7, \quad 12, \quad 13 \quad$ and 16. https://www.echr.coe.int/documents/conven tion_eng.pdf

23. F SALOV v. UKRAINE (Application no. 65518/01) (2005).

ECtHR. http://hudoc.echr.coe.int/app/conversio $\mathrm{n} / \mathrm{pdf} /$ ?library $=\mathrm{ECHR} \& \mathrm{id}=001$ -

70096\&filename $=001$ 70096.pdf\&TID=ihgdqbxnfi

24. Feldman v. Ukraine (no. 2) (Application
no. 42921/09)

ECtHR. http://hudoc.echr.coe.int/app/conversio

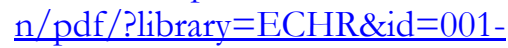

108496 \&filename $=001$ -

$\underline{108496 . p d f \& T I D=\text { ihgdqbxnfi }}$

25. Findlay v. The United Kingdom (Application no. 22107/93) (1997). ECtHR. http://hudoc.echr.coe.int/app/conversio

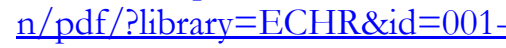
$\underline{58016 \& \text { filename }=001-58016 . p d f}$
26. Gennadi Naoumenko v. Ukraine (Application no. 42023/98) (2004). ECtHR. https://hudoc.echr.coe.int/eng\# $\{\% 22$ ite mid $\% 22:[\% 22001-66182 \% 22]\}$

27. Hoffmann-Riem, W. (2014). The Venice Commission of the Council of EuropeStandards and Impact. European Journal of International Law, 25(2), 579597. https://doi.org/10.1093/ejil/chu029

28. Hossain Mollah, A. (2012). Independence of judiciary in Bangladesh: An overview. International Journal of Law and Management, 54(1), 61-

77. https://doi.org/10.1108/17542431211189605

29. Hrestic, M.-L. (2013). The European Court of Human Rights. A Few Considerations Regarding its Juridical Reasoning. Procedia - Social and Behavioral Sciences, 92, 397402. https://doi.org/10.1016/j.sbspro.2013.08.69 1

30. Judicial Group on Strengthening Judicial Integrity. (2002). The Bangalore principles of judicial conduct. https://www.unodc.org/pdf/crime/corru ption/judicial group/Bangalore principles.pdf

31. Keith, K. J. (2017). Challenges to the Independence of the International Judiciary: Reflections on the International Court of Justice. Leiden Journal of International Law, 30(1), 137154. https://doi.org/10.1017/S092215651600064 $\underline{9}$

32. Kim, J. (2007). The Judiciary's Role in Good Governance in Korea. Policy and Society, 26(2), 15-32. https://doi.org/10.1016/S14494035(07)70106-6

33. Kosař, D., \& Spáč, S. (2018). Conceptualization(s) of Judicial Independence and Judicial Accountability by the European Network of Councils for the Judiciary: Two Steps Forward, One Step Back. International Journal for Court Administration, 37. https://doi.org/10.18352/ijca.284

34. Kovács, K., \& Scheppele, K. L. (2018). The fragility of an independent judiciary: Lessons from Hungary and Poland-and the European Union. Communist and Post-Communist Studies, 51(3), 189

200. https://doi.org/10.1016/i.postcomstud.2018. $\underline{07.005}$

35. Kuznetsov and others v. Russia (Application no. 184/02) (2007). ECtHR. https://www.legislationline.org/docume nts/id/15808

36.le Compte, van Leuven and de Meyere v. Belgium (Application no. 6878/75; 7238/75) 
(1981).

ECtHR. https://hudoc.echr.coe.int/tur\#\{\%22ite mid $\% 22:[\% 22001-57522 \% 22]\}$ (2001).

37. Lucà v. Italy (Application no. 33354/96)

ECtHR. https://hudoc.echr.coe.int/fre\# $\{\% 22$ ite mid\%22:[\%22001-59222\%22]\}

38. Mocan, N., Bielen, S., \& Marneffe, W. (2020). Quality of judicial institutions, crimes, misdemeanors, and dishonesty. European Journal of Political Economy, 61, 101815. https://doi.org/10.1016/i.eipoleco.2019. $\underline{101815}$

39. Moiseyev v. Russia (Application no. 62936/00)

(2008).

ECtHR. http://hudoc.echr.coe.int/webservices/c ontent/pdf/001-88780?TID=ihgdqbxnfi

40. Parliamentary Assembly. (2010). Resolution 1755: The functioning of democratic institutions in Ukraine. https://assembly.coe.int/nw/xml/XRef/ $\underline{\text { Xref-XML2HTML-en.asp? fileid }=17899 \& l a n g=e n}$

41. Piana, D. (2017). Reforming the judiciary through standards: Agency empowerment and centre (re)building in Italy, 2001-2015. International Review of Administrative Sciences, 83(4), 757772. https://doi.org/10.1177/0020852315592022

42. Pradeep M., D. (2019). Legal ResearchDescriptive Analysis on Doctrinal Methodology. https://doi.org/10.5281/ZENODO. $\underline{3564954}$

43. Pullar v. The United Kingdom (Application no. 22399/93) (1996). ECtHR. https://www.bailii.org/eu/cases/ECHR /1996/23.html

44. Remli v France (Application no. 16839/90) (1996).

ECtHR. https://www.legislationline.org/docume nts/id/20771

45. Romanov v. Ukraine (Application no. 63782/11)

(2020).

ECtHR. https://laweuro.com/?p=12096

46. Rudenko, M., Malinovska, I., \& Kravtsov, S. (2021). Justice for Judges in Ukraine: Looking for Peace and Strong Judiciary Institutions in a Sustainable Society. European Journal of Sustainable Development, 10(1), 339. https://doi.org/10.14207/ejsd.2021.v10n1p3 $\underline{39}$

47. Sakara, N. (2021). The Applicability of the Right to a Fair Trial in Civil Proceedings:The Experience in Ukraine. Access to Justice in Eastern Europe,

4(1),

199
222. https://doi.org/10.33327/AJEE-18-4.1$\underline{\mathrm{n} 000053}$

48. Seventh United Nations Congress on the Prevention of Crime and the Treatment of Offenders. (1985). Basic Principles on the Independence of

Judiciary. https://www.ohchr.org/EN/Professiona $\underline{\text { Interest/Pages/IndependenceJudiciary.aspx }}$

49. Simental Franco, V. A. (2017). Transparencia y ética judicial. Cuestiones Constitucionales Revista Mexicana de Derecho Constitucional,

1(36). https://doi.org/10.22201/iii.24484881e.201 7.36.10862

50. Sovtransavto Holding v. Ukraine (Application no. 48553/99) (2002). ECtHR. https://hudoc.echr.coe.int/eng\# $\{\% 22$ ap pno $\% 22:[\% 2248553 / 99 \% 22], \% 22$ itemid $\% 22:[\% 2$ 2001-60634\%22]\}

51. Spano, R. (2021). The rule of law as the lodestar of the European Convention on Human Rights: The Strasbourg Court and the independence of the judiciary. European Law Journal,

eulj.12377. https://doi.org/10.1111/eulj.12377

52. The Committee of Ministers of the Council of Europe. (2010). Recommendation $C M / \operatorname{Rec}(2010) 12$ of the Committee of Ministers to member states on judges: Independence, efficiency and responsibilities. https://search.coe.int/cm/Pages/re sult details.aspx?ObjectID $=09000016805 \mathrm{afb} 78$

53. United Nations. (2015). Resolution Transforming our world: the 2030 Agenda for Sustainable Development (A / RES / 70/1. https://www.un.org/en/development/desa /population/migration/generalassembly/docs/glo balcompact/A RES 701 E.pdf

54. Voigt, S., \& Gutmann, J. (2015). On the wrong side of the law - Causes and consequences of a corrupt judiciary. International Review of Law and Economics, $\quad 43, \quad 156-$ 166. https://doi.org/10.1016/j.irle.2014.04.005

55. Voigt, S., Gutmann, J., \& Feld, L. P. (2015). Economic growth and judicial independence, a dozen years on: Cross-country evidence using an updated Set of indicators. European Journal of Political Economy, 38, 197211. https://doi.org/10.1016/j.ejpoleco.2015.01.0 $\underline{04}$

56. Vuille, J., Lupària, L., Taroni, F. (2017). Scientific evidence and the right to a fair trial under Article 6 ECHR. Law, Probability and Risk, 16(1), $55-$ 68, https://doi.org/10.1093/lpr/mgx001 
Law, Business \& Sustainability Herald

57. Weiden, D. L. (2009). Examining the influence of the European Convention on Human Rights in Northern Ireland courts. The Social Science Journal,

46(1),

150

163. https://doi.org/10.1016/j.soscij.2008.08.001
2021 | Volume 1 | Issue 1

58. Yeung, L. L. (2019). Bias, insecurity and the level of trust in the judiciary: The case of Brazil. Journal of Institutional Economics, 15(1), 163188. https://doi.org/10.1017/S174413741700062 $\underline{5}$ 